\title{
ТРАНСКРАНІАЛЬНА НЕЙРОМОДУЛЯЦІЯ В РЕАБІЛІТАЦІЇ ТА ПСИХОЛОГІЧНОМУ СУПРОВОДІ ДІТЕЙ З ОСОБЛИВИМИ ОСВІТНІМИ ПОТРЕБАМИ
}

Олег Орлов, Інститут спеціальної педагогіки і психології імені Миколи Ярмаченка НАПН України м. Київ, Україна, orlovoleh@gmail.com

Теоретично проаналізовано сучасні технології нейромодуляції та їхню ефективність у реабілітації та психологічному супроводі дітей із порушеннями розвитку як монометод та допоміжний засіб при комплексного мультидисциплінарного підходу до розвитку цих дітей. Коротко представлено історію становлення стимуляції мозку як терапевтичного напряму від стародавніх часів до сучасності. Охарактеризовано інвазивний та неінвазивний підходи до нейромодуляції. Представлено дві основні технології транскраніальної нейромодуляції - магнітну та електричну.

Висвітлено теоретичне підгрунтя повторюваної магнітної транскраніальної стимуляції (rTMS) головного мозку та стимуляції тета спалахами (TBS), транскраніальної електричної стимуляції постійним (tDCS) та змінним (tACS) струмом, випадковим шумом (tRNS).

Наведено відомості щодо ефективності методів нейромодуляції при РАС, СДУГ, ДЦП, епілепсії, депресії, ОКР, ПТСР, біполярному розладі та розладах спектра шизофренії. Описано ефекти комбінованого застосування методів нейромодуляції та навчання.

Ключові слова: мікрополяризація, tDCS, tACS, tRNS, rTMS, TBS.

Олег Орлов, Институт специальной педагогики и психологии имени Николая Ярмаченко НАПУ Украины, г. Киев, Украина, orlovoleh@gmail.com

Транскраниальная нейромодуляция в реабилитации и психологическом сопровождении детей с особыми образовательными потребностями

Теоретически проанализировано современные технологии нейромодуляции $и \quad$ их эффективность в реабилитации и психологическом сопровождении детей с нарушениями развития в качестве монометода и вспомогательного средства при комплексном мультидисциплинарном подходе к развитию этих детей.

Кратко представлена история становления стимуляции мозга как терапевтического направления от древних времен до современности. Охарактеризованы инвазивный и неинвазивный подходы к нейромодуляции. Представлены две основные технологии транскраниальной нейромодуляции - магнитная и электрическая.

Освещены теоретические основы повторяющейся магнитной транскраниальной стимуляции (rTMS) головного мозга и стимуляции тета вспышками (TBS), транскраниальной электрической стимуляции постоянным (tDCS) и переменным (tACS) током, случайным шумом (tRNS).

(C) Орлов 0., 2019 
Приведены сведения об эффективности методов нейромодуляции при РАС, СДВГ, ДЦП, эпилепсии, депрессии, ОКР, ПТСР, биполярном расстройстве и расстройствах спектра шизофрении. Описаны эффректы комбинированного применения методов нейромодуляции и обучения. Ключевые слова: микрополяризация, tDCS, tACS, tRNS, rTMS, TBS

Oleh Orlov, Mykola Yarmachenko Institute of Special Education and Psychology, Mykola Yarmachenko Institute of Special Education and Psychology of the NAES of Ukraine (Ukraine), orlovoleh@gmail.com

\section{Non-invasive brain stimulation in treatment of children and adolescents with disabilities}

Methods of non-invasive brain stimulation (or neuromodulation) including rTMS, TBS, tDCS, tACS, and tRNS are a recent hot topic in applied neuroscience. The efficacy of these methods in treatment of patients with mental disorders and/or developmental disabilities is still being investigated as no consensus between academics has been reached in this area by so far. In Ukraine this area of research is underrepresented in academia. At the same time different methods of NIBS are offered on the market by private practitioners and claimed to be effective e.g. in treatment of autism spectrum disorders.

In this literature review we strive to characterize the main methods of NIBS to further the understanding of strength and limitations of these methods in order to provide Ukrainian practitioners and service receivers with basis for making informed decisions about whether to participate in NIBS interventions.

We describe the neurobiological mechanisms of two major NIBS technologies - transcranial magnetic stimulation (TMS) and transcranial electric stimulation (tES). Also we characterize the main methods of NIBS used today: repeated transcranial magnetic stimulation (rTMS); theta-burst stimulation (TBS); transcranial direct current (tDCS) and alternating current (tACS) stimulation, and transcranial random noise stimulation (tRNS). Finally, we review the evidence for the efficacy of different NIBS approaches in treatment of children and adolescents with psychiatric disorders and developmental disabilities (ASD, ADHD, CP, epilepsy etc),

Keywords: micropolarization, tDCS, tACS, tRNS, rTMS, TBS.

$\Pi$

ередовою світовою тенденцією в організації навчання та розвитку дітей 3 особливими освітніми потребами є перехід до моделі психолого-педагогічного супроводу таких дітей мультидисциплінарними командами фахівців. Інтегрована взаємодія педагогів, психологів, корекційних педагогів, реабілітологів, лікарів та інших спеціалістів забезпечує максимальну ефективність навчання та розвитку дитини відповідно до іiі індивідуальних особливостей завдяки комплексному впливу.

Останніми роками тенденція до міждисциплінарності прослідковується не лише в галузі спеціальної педагогіки й психології, а й у науці загалом. Більшість сучасних підходів в усіх галузях науки передбачає розуміння принаймні елементарних основ дисциплін, дотичних до проблем, що вивчаються. З'являються й окремі наукові напрями, які можуть мати лише міждисциплінарний характер. Таким науковим напрямом є нейронаука - галузь наук про людину, що різноаспектно вивчає нейробіологічні основи ії життя та діяльності. Нейронаука має широкий дослідницький фокус. Широкими також є і перспективи ії практично-

«ОСОБЛИВА ДИТИНА: навчання і виховання», № 3, 2019 
го застосування, оскільки здобутки цієї наукової галузі сприяють щоденній появі нових технологій в медицині, педагогіці, спорті, управлінні, IT тощо.

Однією 3 актуальних тем сучасної нейронауки $є$ нейромодуляція (або нейростимуляція) - технологія впливу на роботу нервової системи (переважно - головного та спинного мозку) за допомогою різних технічних засобів. Науковці вивчають перспективи застосування нейромодуляції в медицині, реабі-

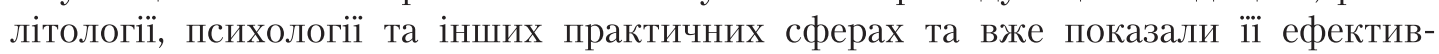
ність для медичного (наприклад, у терапії депресії, персистентного болю тощо) та немедичного (наприклад, для підвищення ефективності навчання, формування мовлення тощо) використання.

Нейромодуляція набуває поширення і в Україні. Однак, якщо в світі ця технологія з'явилась і дотепер вивчається в дослідницьких лабораторіях і лише потім впроваджується у практику, то для наших реалій характерним є поступове поширення послуг з нейромодуляції (нейростимуляції) на ринку замайже повної відсутності доступної для українських фахівців та отримувачівпослуг відповідної теоретико-методологічної бази. Унаслідок утрудненого доступу до результатів клінічних випробувань та заснованих на дослідженнях протоколів використання нейромодуляції як користувачам, так і надавачам послуг важко обрати дієві стратегії застосування цієї перспективної технології з медичною та немедичною метою. Через це ризик неефективного застосування нейромодуляції або навіть ненавмисного нанесення шкоди здоров'ю пацієнтів та клієнтів.

Отже, надзвичайно важливим завданням для ефективного впровадження нейромодуляції в Україні є поширення науково обгрунтованої інформації щодо цієї передової технології. У цьому контексті актуальною виглядає мета публікації цієї статті: охарактеризувати сучасні технології нейромодуляції, описати їхні теоретичні основи та визначити науково обгрунтовані сфери їх застосування в реабілітації та психологічному супроводі дітей з особливими освітніми потребами.

Стимуляція мозку у сучасному iï вигляді відносно широкого поширення набула лише в останні десятиліття, однак поодинокі спроби впливати на роботу людського мозку немедикаментозними засобами відомі ще 3 давніх часів. Наприклад, Скрибоній Ларг, лікар римських імператорів Тиберія та Клавдія, намагався лікувати головний боль, ударяючи в лоб своїх пацієнтів електричним струмом, отриманим від електричних скатів. Після відкриття біоелектрики у XVIII ст. тогочасні дослідники намагались знайти терапевтичне застосування електричного струму, зокрема у лікуванні розладів центральної нервової системи. Так, наприклад, Джованні Альдіні, племінник Луіджі Гальвані, в опублікованій ним у 1803 р. праці описує успішний досвід лікування тяжкої меланхолії (сучасною мовою - депресіі). Досліди з електричних явищ у роботі нервової системи продовжувались та отримали значний поштовх після винайдення на початку XX ст. електроенцефалографії Гансом Бергером. Невдовзі після цього була проведена перша процедура електроконвульсивної терапії, яка вважалась виправданим та ефективним терапевтичним методом лікування в психіатрії аж до початку XXI ст. У 1950-х роках почали проводити перші операції з глибинної стимуляції головного мозку у лікуванні епілепсії. У 1960-1980 рр. почали 
з'являтися перші сучасні неінвазивні технології нейромодуляції (електричної та магнітної відповідно) (Lewis et al., 2016).

Сьогодні використовується два підходи до нейромодуляції - інвазивний та неінвазивний. Розробляються дві основні технології нейромодуляції у відповідності до принципу їхньої дії на нервову систему - електрична та магнітна. Різні технології нейромодуляції застосовуються для впливу на головний та спинний мозок (краніальна та вертебральна нейромодуляція), а також на окремі активні ділянки нервової системи (наприклад, вагальна нейромодуляція, що передбачає стимуляцію блукаючого нерва).

Інвазивний підхід до нейромодуляції передбачає імплантацію спеціальних стимулюючих пристроїв безпосередньо в тіло людини. Інвазивна стимуляція (зокрема, стимуляція глибоких структур мозку, або deep brain stimulation) використовується в терапії хвороби Паркінсона, епілепсії, персистентного болю, резистентної депресії, обсесивно-компульсивного розладу, анорексії. Дослідження показують певну ефективність цього виду нейромодуляції в терапії зазначених та інших розладів. Однак очевидно, що інвазивна нейромодуляція передбачає проведення складних хірургічних втручань, а отже $є$ нерелевантною у контексті теми нашого дослідження. Утім, зацікавлені читачі можуть знайти детальний опис цього методу нейромодуляції у відповідній літературі, наприклад у Papageorgiou et al. (2017).

Неінвазивний підхід до нейромодуляції передбачає вплив на мозок людини іззовні, без будь-якого роду хірургічних втручань. Цей підхід до нейромодуляції має широкий спектр застосувань, які будуть білыш детально описані нижче. Чисельні дослідження можливих негативних ефектів неінвазивної нейромодуляції демонструють ï безпечність. 3-поміж можливих побічних ефектів зазначають головний біль помірного ступеня для транскраніальної магнітної стимуляції та незначне свербіння або подразнення в місцях контакту шкіри та електроді в для транскраніальної (головного мозку) чи трансвертебральної (спинного мозку) електричної стимуляції. Інші побічні ефекти, такі як підвищення емоційної збудливості, епілептичні напади чи галюцинації, трапляються вкрай рідко. Загалом транскраніальна стимуляція вважається безпечною для дорослих та дітей (Nikolin et al., 2018; Taylor, Galvez, \& Loo, 2018).

В основі методу транскраніальної магнітної стимуляції (далі - TMS) лежить принцип електромагнітної індукції: на електромагнітну котушку приладу для TMS подається електричний струм, який викликає появу в котушці сильного магнітного поля; магнітне поле в котушці викликає електричне поле у біологічних тканинах, що знаходяться близько до котушки апарату TMS. Це електричне поле впливає на роботу нервової системи через електрохімічну природу нервових імпульсів, які лежать в основі iї функціонування. При цьому навіть сильне магнітне поле найбільш потужних апаратів TMS не проникає всередину черепної коробки глибше, ніж на 3 см. Тобто, стимуляції піддаються переважно коркові структури головного мозку (Klomjai, Katz, \& Lackmy-Vallée, 2015).

На практиці найчастіше застосовуються протоколи повторюваної TMS (rTMS) та TMS тета спалахами (TBS). У першому випадку цільова ділянка 
кори головного мозку стимулюється електромагнітними імпульсами, що повторюються 3 низькою (до 1 Гц) чи високою (понад 5 Гц) частотою. В результаті у цій ділянці стимулюються процеси гальмування чи збудження відповідно. У другому випадку цільова ділянка кори мозку стимулюється серіями електромагнітних імпульсів із високою частотою та короткими інтервалами між серіями імпульсів (по три такі імпульси з частотою 50 Гц та паузою між імпульсами у 0,2 с). Цей протокол має одночасно ефекти збудження та гальмування i позитивно впливає на нейропластичність (підсилення чи послаблення зв'язків між нейронами) (Klomjai, Katz, \& Lackmy-Vallée, 2015).

Курс терапії TMS передбачає щоденні сесіі TMS протягом 4-6 тижнів. Під час першої сесії уточнюється протокол TMS. Для цього параметри TMS підлаштовують відповідно до індивідуальної чутливості пацієнта до магнітної стимуляції та локалізації функціональної зони інтересу (тобто точного розташування необхідної ділянки кори головного мозку), оскільки ці характеристики є особливими в кожної людини. У подальшому під час сесій TMS пацієнт має спокійно сидіти в кріслі. Від тривалості сесії TMS залежить тривкість iii ефекту. Зазвичай сесіі TMS тривають близько півгодини. Після завершення курсу TMS терапевтичний ефект зберігається протягом тривалого часу (Janicak et al., 2010).

Дослідження показують значну ефективність TMS у терапії широкого спектра психічних розладів та у психологічному супроводі дітей та підлітків з особливими освітніми потребами. Також у серії досліджень показано позитивний вплив TMS на мисленнєву діяльність здорових людей.

Так, при розладах аутистичного спектра (PAC) TMS застосовується переважно для стимуляції дорсолатеральної префронтальної кори (ДЛПФК) та моторної кори (МК) з метою активації ГАМК-ергічних інтернейронів та відповідного відновлення балансу між процесами гальмування та збудження.

3-поміж позитивних ефектів TMS при РАC відмічають поліпшення уваги та соціальної поведінки, зниження схильності до повторюваних дій, дратівливості та гіперактивності. При синдромі дефіциту уваги і гіперактивності (СДУГ) також стимулюється ДЛПФК та МК. Серед ефектів TMS відмічається зниження симптомів СДУГ, зокрема поліпшення уваги та зниження гіперактивної та імпульсивної поведінки. При тикових розладах та синдромі Туретта стимулюється додаткова моторна кора (ДМК). 3-поміж ефектів відмічається зниження тикових проявів та симптомів супутніх психічних порушень (наприклад, тривоги) (Finisguerra, Borgatti, \& Urgesi, 2019). Стимуляція первинної моторної кори (ПМК) у комбінації з функціональним тренінгом значно поліпшує дрібну моторику при дитячому церебральному паралічі (Rajapakse \& Kirton, 2013).

Також дослідники відмічають позитивні ефекти транскраніальної магнітної стимуляції ДЛПФК та скронево-тім'яних зон кори при розладах спектра шизофренії (полегшення позитивної та негативної психотичної симптоматики, зокрема аудіальних галюцинацій, позитивний вплив на когнітивне функціонування); стимуляції ДЛПФК при депресивних розладах (антидепресантний 
ефект та позитивний вплив на когнітивне функціонування), панічному розладі (антидепресантний ефект), посттравматичному стресовому розладі (полегшення основних симптомів), біполярному розладі (зниження маніакальних проявів); стимуляції ДЛПФК, ДМК та орбітофронтальної кори при обсесивно-компульсивному розладі (антидепресантний ефект та зниження обсесій та компульсій) (Escribano et al., 2019).

У серії досліджень впливу TMS на мисленнєву діяльність здорових людей продемонстровано позитивний вплив цього методу нейромодуляції на швидкість та точність у різноманітних інтелектуальних вправах. В основі цих позитивних ефектів лежать два нейробіологічні механізми: TMS може стимулювати ділянки мозку, задіяні в опрацюванні інформації, а також гальмувати інші, не задіяні у відповідній мисленнєвій діяльності ділянки мозку для більш ефективного перерозподілу ресурсів мозку (Luber \& Lisanby, 2014).

Отже, TMS є ефективним самостійним засобом терапії значної кількості розладів і може використовуватись як допоміжний засіб у психологічному супроводі й реабілітації дітей та підлітків з особливими освітніми потребами. Перспективним є використання TMS для підвищення ефективності інтелектуальної діяльності. Водночас, TMS передбачає використання громіздкої дороговартісної апаратури та спеціально обладнаних приміщень. Тому, застосування цього методу є дещо обмеженим з економічних та практичних міркувань, хоча має сенс в контексті роботи мультидисциплінарних команд супроводу у колективному користуванні обладнанням.

Іншим сучасним методом нейромодуляції є транскраніальна електрична стимуляція (tES). Переважно використовується транскраніальна електрична стимуляція постійним струмом (tDCS, також відома як транскраніальна мікрополяризація), змінним струмом (tACS) та випадковим шумом (tRNS). При застосуванні кожного з цих методів tES більша частина електричного струму розповсюджується по поверхні скальпу і лише незначна частина струму проникає безпосередньо в мозок. Тому, як і у випадку із TMS, стимулюється переважно кора головного мозку. Розробляють технології tES глибинних структур мозку, однак вони ще недостатньо вивчені та далекі до впровадження у практику.

Принцип дії tDCS полягає в стимуляції головного мозку постійним електричним струмом слабкої сили (близько 1-2 мА) 3 метою поляризації чи деполяризації клітинних мембран нейронів (зменшення чи підвищення схильності нервової клітини до передачі нервового імпульсу відповідно), які знаходяться безпосередньо під електродами пристрою електричної нейромодуляції. Тобто, застосування tDCS дає можливість селективно «вмикати» чи «вимикати» бажані функціональні зони кори головного мозку. Також tDCS впливає на роботу NMDA-рецепторів (підтип рецепторів глутамату - нейротрансмітера, що регулює процеси збудження) та викликає ефекти, подібні до довготривалої потенціації - посилення синаптичної передачі між нейронами, що зберігається протягом тривалого часу і лежить в основі клітинних механізмів пам'яті та навчання. Учені повідомляють і про інші біохімічні ефекти tDCS 
та інших видів tES, однак дослідження в цій сфері лише починаються (Kuо, Polan a, \& Nitsche, 2016).

При застосуванні tACS використовується змінний струм різної частоти (переважно від одного Гц до кількох кГц або навіть сотень кГц). Метою застосування tACS є вплив на частоту електричних коливань мозку в ділянках інтересу. Електричні коливання у ділянках, що піддаються дії tACS, синхронізуються із заданою частотою нейромодуляції. Це дає змогу селективно збуджувати чи гальмувати відповідні ділянки кори мозку, синхронізувати чи розсинхронізовувати ї. Також дослідження показують, що tACS із частотою коливань, що виходить за межі нормальної частоти електричних коливань головного мозку людини (тобто, перевищує $100-200$ Гц), істотно не впливає на коливання у ділянках мозку, які піддаються стимуляції, однак викликає короткочасне підвищення нейропластичності.

Під час застосуванні tRNS використовують змінний струм із частотою та амплітудою, що встановлюється випадковим шляхом та постійно змінюється. Частота змінного струму зазвичай лежить у межах від 0,1 до 640 Гц та імітує білий шум. Цей метод нейромодуляції перешкоджає звичайній роботі відповідних функціональних регіонів інтересу кори головного мозку, що може бути корисним, наприклад, для зміни неадаптивних звичних форм поведінки. Також tRNS підвищує чутливість нервової системи до подразників (Moreno-Duarte et al., 2014).

Курс терапії tES може складатись із різної кількості сесій залежно від протоколу, однак типовим випадком є щоденна стимуляція протягом 10 днів. Зазвичай сесії tES тривають близько 20 - 30 хв. Обладнання для tES є доволі компактним, тому під час сесії пацієнти можуть займатись різними активностями. Це дозволяє ефективно комбінувати сесії tES із ігровою чи навчальною діяльністю, а також із фізичними вправами.

У численних дослідженнях ефектів tES продемонстрована ефективність цієі групи методів у терапії широкого спектра неврологічних та психічних порушень, а також у навчанні та психологічному супроводі дітей та підлітків, зокрема тих, які мають порушення розвитку.

Так, tDCS ДЛПФК у дітей з РАC сприяє підвищенню функціональної коркової інтеграції та нормалізації альфа-ритмів та викликаних потенціалів, має тривкий позитивний вплив на сприймання, навчання мовленню, комунікацію, зменшує вираженість негативних симптомів, характерних для PAC; tDCS ДЛПФК у дітей зі СДУГ викликає уповільнення мозкових ритмів та має позитивний вплив на увагу та самоконтроль, зниження кількості помилок у навчальних завданнях та підвищення швидкості їх вирішення, має позитивний вплив на поведінку. Застосування tDCS скронево-тім'яних регіонів мозку при дислексії має тривкий позитивний вплив на правильність та швидкість читання (Finisguerra et al., 2019). При ДЦП та дистонії tDCS ПМК та ДЛПФК сприяли розвитку в дітей моторики, полегшували вольовий контроль моторної активності. Нейромодуляція з використанням tDCS ділянок кори мозку, у яких спостерігається епілептична активність, дає змогу нормалізувати роботу таких ділянок (RiveraUrbina et al., 2017). 
Застосування tDCS ДЛПФК дає можливість значно зменшити симптоми депресіі; tDCS та tRNS нейромодуляція ДЛПФК та скронево-тім'яного вузла при розладах спектра шизофренії знижує позитивні та негативні симптоми цього розладу; tDCS та tRNS нейромодуляція ДМК зменшує вираженість симптомів OKР; tDCS нейромодуляція ДЛПФК знижує симптоматичні прояви розладів, пов'язаних з вживанням психоактивних речовин та розладів харчової поведінки (Tortella et al., 2015).

Окремо варто відмітити серію досліджень впливу tES на ефективність навчання. Стимуляція зон кори, що задіяні в обробці специфічної для конкретних завдань інформації (наприклад, стимуляція ДЛПФК при навчанні плануванню та вольовій саморегуляції, тім'яних зон кори при навчанні рахуванню об'єктів тощо), має позитивний вплив на робочу пам'ять, здатність до планування, довільну увагу, вольову саморегуляцію, здатність рахувати та виконувати арифметичні діï (Elmasry, Loo, \& Martin, 2015). Загалом дослідники вважають комбінацію tES та навчання чи психокорекційних втручань ефективнішою, ніж застосування іх поодинці. Утім, такий комбінований підхід через свою інноваційність все ще потребує детального вивчення.

Отже, різні форми tES мають широкий спектр застосування в медичному та немедичному контексті. Перевагами методів tES над TMS є відносно невисока вартість, компактність та портативність необхідного обладнання, відсутність акустичного під час роботи, значно менша кількість та інтенсивність побічних ефектів. Транскраніальна нейромодуляція електричним струмом є ефективною як монометод, а також значно підвищує ефективність більш традиційних форм терапії. У психологічному супроводі дітей та підлітків з особливими освітніми потребами tES може використовуватись як ефективне медичне втручання в контексті роботи мультидисциплінарної команди супроводу. Перспективним напрямом наукових пошуків $є$ розроблення та впровадження методик немедичного застосування комбінації tES та навчання навичок у психологічному супроводі та реабілітації дітей та підлітків з особливими освітніми потребами.

\section{REFERENCES (TRANSLATED AND TRANSLITERATED)}

1. Elmasry J., Loo C., $\mathcal{E}$ Martin D. (2015). A systematic review of transcranial electrical stimulation combined with cognitive training. Restorative neurology and neuroscience, 33(3), $263-278$.

2. Escribano B. M., Fern M., Feijoo M., Aguera E., E Tunez I. (2019). Effects and Therapeutic Use of TMS in Psychiatric Disorders: An Evidence-Based Review.

3. Finisguerra A., Borgatti R., E Urgesi C. (2019). Non-invasive brain stimulation for the rehabilitation of children and adolescents with neurodevelopmental disorders: a systematic review. Frontiers in psychology, 10.

4. Janicak P. G., Nahas Z., Lisanby S. H., Solvason H. B., Sampson S. M., McDonald W. M., ... E O'Reardon J.P. (2010). Durability of clinical benefit with transcranial magnetic stimulation (TMS) in the treatment of pharmacoresistant major depression: assessment of relapse during a 6-month, multisite, open-label study. Brain stimulation, 3(4), 187-199.

«ОСОБЛИВА ДИТИНА: навчання і виховання», № 3, 2019 
5. Klomjai W., Katz R., E Lackmy-Vallée A. (2015). Basic principles of transcranial magnetic stimulation (TMS) and repetitive TMS (rTMS). Annals of physical and rehabilitation medicine, 58(4), 208-213.

6. Kuo M. F., Polan a R., EF Nitsche M. (2016). Physiology of transcranial direct and alternating current stimulation. In Transcranial Direct Current Stimulation in Neuropsychiatric Disorders (pp. 29-46). Springer, Cham.

7. Lewis P. M., Thomson R. H., RosenfeldJ. V., Eं Fitzgerald P. B. (2016). Brain neuromodulation techniques: a review. The neuroscientist, 22(4), 406-421.

8. Luber B., Eं Lisanby S. H. (2014). Enhancement of human cognitive performance using transcranial magnetic stimulation (TMS). Neuroimage, 85, 961-970.

9. Moreno-Duarte I., Gebodh N., Schestatsky P., Guleyupoglu B., Reato D., Bikson M., Ë Fregn, F. (2014). Transcranial electrical stimulation: transcranial direct current stimulation (tDCS), transcranial alternating current stimulation (tACS), transcranial pulsed current stimulation (tPCS), and transcranial random noise stimulation (tRNS). In The stimulated brain (pp. 35-59). Academic Press.

10. Nikolin S., Huggins C., Martin D., Alonzo A., E $\mathcal{F}$ Loo C. K. (2018). Safety of repeated sessions of transcranial direct current stimulation: a systematic review. Brain stimulation, 11(2), 278-288.

11. Papageorgiou P. N., Deschner J., E F Papageorgiou S. N. (2017). Effectiveness and adverse effects of deep brain stimulation: umbrella review of meta-analyses. Journal of Neurological Surgery Part A: Central European Neurosurgery, 78(02), 180-190.

12. Rajapakse T., E Kirton A. (2013). Non-invasive brain stimulation in children: applications and future directions. Translational neuroscience, 4(2), 217-233.

13. Rivera-Urbina G. N., Nitsche M. A., Vicario C. M., EF Molero-Chamizo A. (2017). Applications of transcranial direct current stimulation in children and pediatrics. Reviezes in the Neurosciences, 28(2), 173-184.

14. Taylor R., Galvez V., E Loo C. (2018). Transcranial magnetic stimulation (TMS) safety: a practical guide for psychiatrists. Australasian Psychiatry, 26(2), 189-192.

15. Tortella G., Casati R., Aparicio L. V., Mantovani A., Senço N., D’Urso G., ... EF Junior B. D. $S$. P. (2015). Transcranial direct current stimulation in psychiatric disorders. World journal of psychiatry, 5(1), 88. 